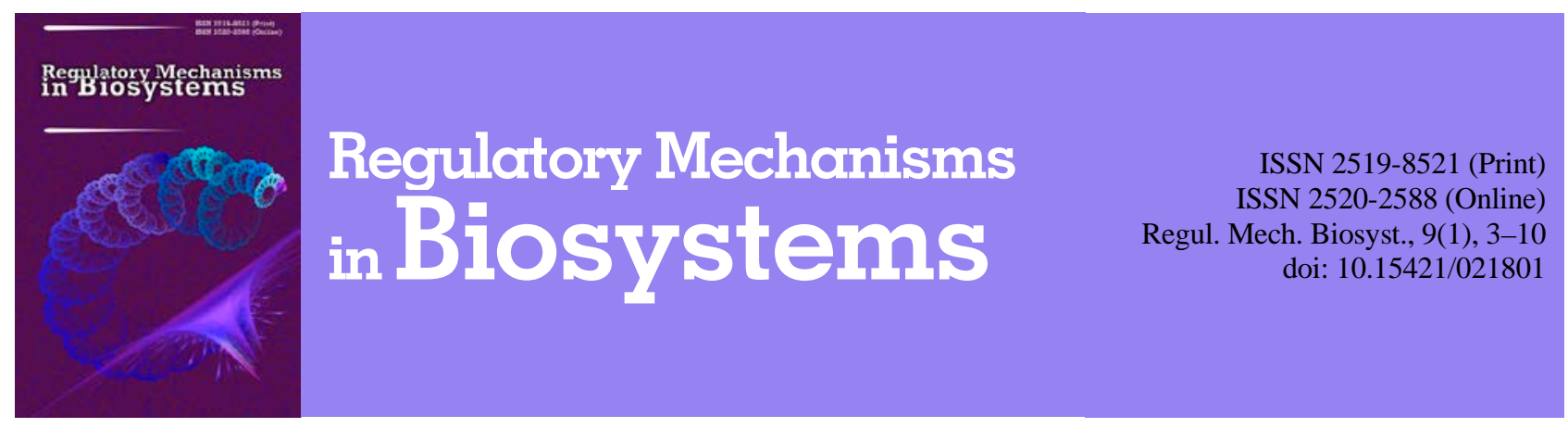

\title{
Theoretical and experimental substantiation of a fungal therapeutic drug with immunomodulating and antitumor action according to the authors' prescription
}

\author{
V. A. Kuchmistov*, N. O. Koziko**, O. F. Kuchmistova*, \\ O. P. Shmatenko*, V. O. Tarasenko*, A. O. Drozdova*** \\ *Ukrainian Military Medical Academy, Kyiv, Ukraine \\ **National Medical University named after A. A. Bogomoletz, Kyiv, Ukraine \\ ***National Medical Academy of Postgraduate Education named after P. L. Shupyk, Kyiv, Ukraine
}

Article info

Received 11.01.2018

Received in revised form 29.01.2018

Accepted 02.02.2018

Ukrainian Military Medical Academy, Moskovs'ka st., 45/1, Kyiv, 01015, Ukraine.

Tel.: +38-050-334-86-47.

E-mail:

victor.kuchmistov@gmail.com

Bogomolets National Medical University, Pushkinska st., 22, Kyiv, 01601, Ukraine.

Tel.: +38-068-594-67-95.

E-mail: nata.koziko@gmail.com

National Medical Academy of Postgraduate Education named after P. L. Shupyk, Dorogozhitska st., 9 , Kyiv, 04112, Ukraine Tel.: +38-066-364-84-14. E-mail: drozdova82@ukr.net
Kuchmistov, V. A., Koziko, N. O., Kuchmistova, O. F., Shmatenko, O. P., Tarasenko, V. O., \& Drozdova, A. O. (2018). Theoretical and experimental substantiation of a fungal therapeutic drug with immunomodulating and antitumor action according to the authors' prescription. Regulatory Mechanisms in Biosystems, 9(1), 3-10. doi: 10.15421/021801

The article is devoted to a promising direction in pharmacological mycology and biotechnology, namely the use of Basidiomycetes as a biologically active substance for preparation of pharmaceuticals. The anticancer and immunostimulating properties of Basidiomycetes result from the structural characteristics of the polysaccharides: the presence of $\beta-(1 \rightarrow 3)$ connections in the main chain and an additional $\beta-(1 \rightarrow 6)$ branched part of glucans. Attention is focused on Shiitake mushrooms (Lentinula edodes) as a unique biosystem with a strong ability to be involved in the regulatory mechanism of human immunomodulation. The purpose of the theoretical and experimental study is development of a pharmaceutical preparation from Shiitake biomass (including its immune cells), the effectiveness of which is considered from the standpoint of the chemistry of natural compounds. Having a 3000-year history of cultivation and application, this mushroom is again of interest to scientists around the world because of investigation into its therapeutic and prophylactic potentials. For the first time, the biotechnological method of cultivating $L$. edodes biomass was developed with the use of deep cultivation, adapted to the plant raw material base of Ukraine. Malt wort was used as a nutrient medium without processing Humulus lupulus. The analysis of research and preclinical studies of specific activity of the designated biosystem showed a steady increase in human immune status, particularly the antitumor status. This gives special relevance to the evaluation of the properties of the designated biosystem in order to further develop the corresponding fungo-therapeutic immunomodulatory and antitumor drug. According to the results of technological research: physico-chemical characteristics of Shiitake biomass dry powder (including crystallographic) were studied; the possibility of its tableting using only antifriction auxiliaries was substantiated; the optimum technology of tablet manufacturing with an operating name "Shitavit" was presented, an integrated approach to its creation was presented, the qualitative and quantitative composition of the drug was experimentally developed. The direct compression method was rejected due to unsatisfactory performance of all samples of tablets. The chosen technology of using preliminary granulation and the possibility of short-term contact of the L. edodes dry powder with a granulation liquid and an adjustable temperature regime allows all the properties of the biologically active substances of the designated raw material to be preserved. The research results for all series of the designated object showed relative stability of parameters for all indicators in laboratory samples. The information presented in this article is a guide to further research, necessary for a better understanding of the healing properties of fungal polysaccharides, increasing the use of broad-spectrum fungi-based preparations,leading to improvement of the quality of human life.

Keywords: Shiitake fungus; Lentinula edodes; tablets; immune resistance; antitumor effect

\section{Introduction}

Enhancement of immunity to certain diseases remains one of the major problems of modern medicine. Analysing various literature references regarding therapy of such diseases, it is worth mentioning that typically heath-related conditions are not the only factor, but also a complex of simultaneous processes and general overall vulnerability. Clinical settings require combined therapy, thus the purpose of the pharmacotherapy of immunological diseases is to effect different components of the immune system (Shah et al., 2011; Xu et al., 2014). Attention is being increasingly dedicated to the examination of the biological effect of fungi-based preparations and Basidiomycetes in particular. In general, more than 2,000 species of edible and/or medicinal fungi have been identified, many of which are widely consumed, stimulating much research on their health-promoting properties (Friedman, 2016). In the last decades the therapeutic properties of fungus in naturally produced pharmaceuticals have been the center of intensive research (Puchkova \& Shcherba, 2006; Rao et al., 2009; Ganeshpurkar et al., 2010; Ren et al., 2012; Mizuno \& Nishitani, 2013; Giavasis, 2014; Meng et al., 2016; Zhang et al., 2016).

Accelerated progress in mushroom growing in many countries (Japan, China, South Korea, USA, Canada, and France) within the last 
30-40 years is based on modern biotechnologies (Meng et al., 2016). This equates to control of the most important natural functions of fungus and obtaining of large crops of fungi kames as a valuable material to obtain broad-spectrum pharmaceutical substances. Global manufacturing of cultivated fungi-based pharmaceuticals brings in a revenue of \$1.2 billion annually (Welbaum, 2015; Krasnopol'skaya et al., 2016). The need to develop similar pharmaceuticals in Ukraine is unquestioned not only from the perspective of clinical implementation but also in terms of the possibility of mainstream use with the purpose of immunodeficiency treatment.

One of five most common edible fungi in the world is Shiitake (Lentinula edodes, Pleurotaceae), the natural distribution of which includes the warm and humid climate zones of Southeast Asia. Shiitake fungus leads by volume in fungus cultivation worldwide, and the global production of Shiitake fungal mycelium since the beginning of the 21st century has increased to approximately 800 thousand tonnes annually (Babickaya et al., 2009; Meng, 2016). Only champignon fungus (Agaricus bisporus) production volumes can be compared with production of Shiitake (Taufiqur, 2012).

Currently, more than $2 / 3$ of the global Shiitake production is based on extensive rearing, where the fungus is bedded on the freshly-cut deciduous trees stumps (e.g. Chinkapin (Castanopsis), oak, maple tree, hornbeam, poplar, alder, mulberry, etc.) The experiential interest consists in the submerged cultivation methods of Shiitake fungus (Puchkova \& Shcherba, 2006; Hearst et al., 2009; Pashev et al., 2009; Zhang et al., 2016). Its advantages include the possibility of growing fungus during the whole year; stable high yield by virtue of creating optimal conditions for obtaining the biomass; usage of a wide range of cellulose herbal substrate and lignin-containing agricultural and industrial wastes; short production cycle (8-10 weeks); automation and mechanisation of the technological process. The submerged cultivation is aimed at obtaining a considerable amount of the good quality seed grain at the transfer from industrial production of fungus kames to the production of the biomass with its further processing into biologically active substances (BAS), pharmaceuticals and separate chemicals desorbing.

Shiitake is considered a medicinal fungus in some forms of conventional medicine. Over the past decade its mineral vitaminous and amino acid profile has been discovered, which defines its high biological value; enhancement of energy metabolism of the human body, emotional lability, hypermnesia, a decrease of chronic fatigue syndrome, improvement of CNS activity and the cardiovascular system, improvement of immune status, etc. (Malitikov, 2013; Friedman, 2016) (Table 1).

Table 1

Complete mineral-vitamin formula of $L$. edodes

54.3 g Carbohydrate; 22.25 g Protein; 19.0 g Water; 2.5g Fiber; $0.75 \mathrm{~g}$ Leach; $0.5 \mathrm{~g}$ Lipid; $0.217 \mathrm{~g}$ Vitamin $\mathrm{B}_{2}$ (Riboflavin); $304.0 \mathrm{mg}$ Potassium; $230.0 \mathrm{mg}$ Mangan; $142.0 \mathrm{mg}$ Cuprum; $112.0 \mathrm{mg}$ Phosphorus; $20.0 \mathrm{mg}$ Magnesium; $9.0 \mathrm{mg}$ Sodium; In $\quad 4.0 \mathrm{mg}$ Vitamin $\mathrm{B}_{3}$ (Niacin, Nicotinic acid or Vitamin PP); $2.0 \mathrm{mg}$ calculation Calcium; $1.5 \mathrm{mg}$ Vitamin $\mathrm{B}_{5}$ (Pantothenic acid); $1.03 \mathrm{mg}$ Zinc; to $100.0 \mathrm{~g} \quad 0.41 \mathrm{mg}$ Ferrum; $0.293 \mathrm{mg}$ Vitamin $\mathrm{B}_{6}$ (Pyridoxine); $0.10 \mathrm{mg}$ Copper; $0.015 \mathrm{mg}$ Vitamin $\mathrm{B}_{1}$ (Thiamine); $325.0 \mathrm{mcg}$ Vitamin A (Acerophotol); 230.0 mcg Manganese; 13.0 meg Vitamin B9; (Folic acid); 5.7 mcg Selenium; 4.15 mcg Vitamin $B_{12}$ (Cyanocobalamin); $0.4 \mathrm{mcg}$ Vitamins of group D (Cholecalciferol, Ergocalciferol)

A proteinous strand of this fungus includes, inter alia, a complete set of all 22 essential amino acids, which is an exceptional property in any product (Sreenivasan et al., 2010). According to other sources, using the method of ion-column chromatography, 19 amino acids were found in dry powder of Shiitake fungus biomass (including 7 indispensable amino acids: Lysine, Threonine, Valine, Methionine, Leucine, Phenylalanyl), using the method of atomic emission and atomic adsorption analysis with flame atomisation - 8 micro- and macro elements (Sodium, Potassium, Calcium, Magnesium, Zinc, Ferrum, Mangan, Cuprum) were found (Pashev et al., 2010; Drori et al., 2016; Friedman, 2016). The examined object is richer in amino acid content than soy, beans, and corn. In particular, the immunomodulatory, antitumoral and antiviral activity of Shiitake fungus is of major interest in the XXIst century, taking into account that humanity still has no effective medicine to control certain widespread diseases. Among medicinal fungi with antineoplastic activity, $L$. edodes is the leader according to its immunomodulatory properties and surpasses Reishi fungus (Ganoderma lucidum) (Mizuno, 1997; Puchkova \& Shcherba, 2006; Hearst et al., 2009; Taufigur, 2012).

Tetsuro Ikekawa (Japan) defined the chemical structure of immunomodulatory 1,6-b-complex of Shiitake kames that are extracted with hot water back in 1969 (Mizuno \& Nishitani, 2013). The next decade was dedicated to intensive research on the immunomodulatory activity of touchwood constituents and pure grown fungus of different systemic groups. Research findings on such immuno-amplifiers extracted from Basidiomycetes as lentinan, schizophyllan, krestin, also glucans and mannans of certain types of ascomycetes have been regularly presented, starting from the 1st International Conference on Immunopharmacology (1980, Brighton, UK), International Symposium on Immunomodulators of Microbial Origin (1981, Osaka, Japan), Microbiologists' Association Congress (1982, Budapest, Hungary), and at the 2nd International Conference on Immunopharmacology (1982, Washington, USA) there were numerous submissions on research into some immunostimulants of Basidiomycetes (lentinan, schizophylilan, Krestyn), glucans and mannans, from some types of fungi from the phylum Ascomycota. Scientists arrived at the conclusion that all immuno-amplifiers are polysaccharides, regardless of the primary structure and impact particularities (Minato \& Mizuno, 2001; Bisen et al., 2010; Ren et al., 2012). Research in this direction continues to be intensively conducted (Jones, 1995; Feofilova, 2004; Rao et al., 2009; Pashev et al., 2010; Shen et al., 2011; Drori et al., 2016; Zhang et al., 2016). Currently, Shiitake is considered to the most extensively studied medicinal fungus (Welbaum, 2015).

The widespread use of polysaccharides is based on the flexibility of its effect on the immune system as an immunomodulation factor. The general epiphylaxis derives from the direct effect of immunomodulators on maturation, proliferation, and differentiation of immunocytes responsible for humoral and cellular self-protection factors. This permits the use of pharma drugs made of higher basidiomycetes in immuno-correcting therapy (Jones, 1995; Feofilova, 2004; Minato \& Mizuno, 2001; Il'inskikh, 2012; Meng et al., 2016).

L. edodes contains a lentinan polysaccharide complex (Lentinan) unique, in its nature, which has no equal in the plant kingdom (Friedman, 2016) (Fig. 1).

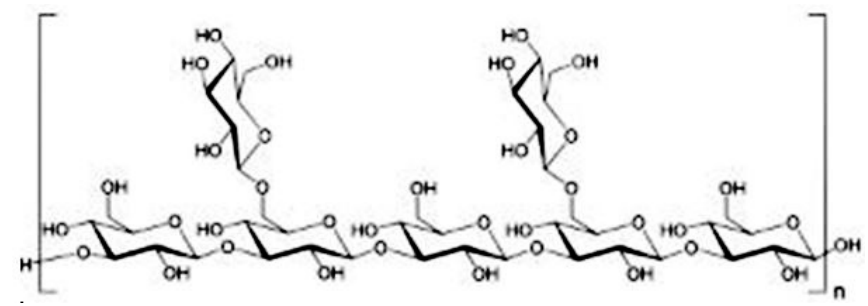

Fig. 1. Basic structure of Lentinan, isolated from the Shiitake fungus

The specified substance stimulates the antineoplastic activity of the immune system, which relies on the ability to increase the generation of perforin polymer protein, attack atypical cells and destroy them, at the same time potentiate the increase of the quantity of natural killer cells (NK-cells), T-lymphocytes fractions (cytotoxic T-cell and T-helpers), as well as cachectin of benign (myoma, fibroma, mastopathy, prostatic hyperplasia) and malignant neoplasms (cancer, sarcoma, lymphoma, melanoma) (Shah et al., 2011). In vitro test results show that depending on the concentration of lentinan, the double increase of $\mathrm{r}$-interferon level in leukocytes occurs, and interferon increases double to fourfold in relation to control (Lindequist et al., 2005; Puchkova \& Shcherba, 2006).

High concentration of natural antioxidants sustains radio protective properties, which help to offset the impact of free radicals, which are able to turn normal cells into nosogenic. First, it is L-ergothioneine (a powerful antioxidant) - in its quantitative content, Shiitake fungus is unrivalled (Jones, 1995). Later, scientists were able to isolate an extract from the spawn of this fungus ( $L$. edodes mycelium extract, LEM), which also showed outstanding results in therapy of oncological 
diseases (Sreenivasan et al., 2010; Xu et al., 2014). The foregoing demonstrates the uniqueness of the selected research target, the effectiveness of which is considered from the standpoint of the chemistry of natural products.

Consequently, taking to account the importance of preventive health care of the population in Ukraine, the matter of obtaining valuable bioproducts and adaptogens is a priority and requires a practical prompt solution. Therefore, the analysis and consolidation of literature data with regard to the modern aspects of the use of the medicinal fungus, L. edodes, and, in particular, the technology and formulation development of medication products based on it is a challenging issue.

\section{Materials and methods}

Research target - Shiitake fungi biomass dry powder.

Topics examined:

- physiochemical characteristic of the biologically active excipient L. edodes dry powder (crystallographic indicants), the practicability of the possible tabletting of the target;

- evaluation of technological properties of tableting blend on the mentioned vehicle (flowability, compression, tapped density, moisture content);

- in-depth study of the possibility of granulation and compression (main phases of tableting process), selected tableting process validation under codename "Shytavit";

- examination of certain of the tablets' quality attributes (disintegration and solubility, hardness and friability tests) according to modern requirements.

For the purpose of finding solutions to the abovementioned tasks, standard research methods, stipulated in test assessment reference: State Pharmacopoeia of Ukraine (SFU) which is brought up with European Pharmacopoeia (Ph. Eur.) in terms of pharmaceuticals production, were used (Ph. Eur., 2014; Hryzodub et al., 2015).

Crystallographic core data of the research target's parts was evaluated by way of light-optical microscopy method with the use of target's visual analysis.

Crystallinity was investigated with an electron microscope MBI-15 (200x magnification), which gave an opportunity to distinguish the shape and the surface of crystals, as well as particles, average linear dimensions according to procedures developed by the State Scientific Pharmaceuticals Centre (Kyiv, Ukraine). The image was displayed on computer monitor from the microscope via Sony CCD-IRIS camera (Pashev et al., 2009).

For specific particles on photographs, a corresponding regular geometric shape was adjusted and dimensions (length and width) were measured considering the zoom. Form factor indicant, which provides a possibility to outline the isometric level of the powder, it was defined as a ratio of particles' average width ( $\mathrm{W}, \mathrm{mum})$ to the particles' average length (L, mum), using formula (1):

$$
K=\frac{W}{L}
$$

It has been established that $K>0.5$ (up to 1 ) for isometric particles and $\mathrm{K} \leq 0.5$ for anisometric particles.

Flowability is one of the most important parameters which impacts technological processes of processing of loose materials, starting from the transporting process to the production of the end formulation (according to divisions 2.9.16. 2.9.36 of SFU, Hryzodub et al., 2015). The definition was conducted using a standard vibratory device, model VP-12-A manufactured at Plant of Production Manufacturing Machinery (Mariupol, Ukraine), after bumping down for $20 \mathrm{~s}$. Flowability measure $\left(\mathrm{V}_{\mathrm{o}} \mathrm{kg} / \mathrm{s}\right)$ was defined as a ratio of sample weight $(\mathrm{m}, \mathrm{kg}$ ) to the full duration of test run (t, s), using formula (2):

$$
V_{c}=\frac{m}{t \times 20}
$$

Direct compression lines the aptitude of the powder to create stable structural systems as a result of particles' attraction under pressure. For determination of dispensing $0.3 \mathrm{~g}$ was pressed in a pill $9 \mathrm{~mm}$ in diameter using a hydraulic press with $120 \mathrm{MPa}$ compacting pressure. After pressing out, the pill was pushed out from matrix with lower punch and the hardness index was determined (n, N) by the ratio of crushing load (P, Pa) to the basic tablets' parameters: its height (h, mm) and diameter (d, mm), using formula (3):

$$
n=\frac{P}{d \times h}
$$

Bulk density (mass) is the characteristics of the powder which reflects heaping of its particles thus outlining the powder's aptness to fill the unit of volume, which depends on unit weight and dispersity, form and powder particles' surface texture (according to divisions 2.9.15, 2.9.34 of SFU, Hryzodub et al., 2015).

For determination of exact dispensing of the powder it (approx. $10 \mathrm{~g}$ ) was placed in a graduated glass cylinder, fixed on 545-AK-3 apparatus manufactured by Plant of Production Manufacturing Machinery (Mariupol, Ukraine). Incremental mechanism lifted the cylinder with powder up to a certain height, from which the cylinder swooped down, hitting into a special device, afterwards was lifted up again to the upper level. By virtue of numerous impulses over the board, powder compaction took place. The vibration amplitude - 35-40 mm, impact frequency - $150 \mathrm{imp} . / \mathrm{min}$. After settling the constant powder level in, the tapped density $\left(\mathrm{P}, \mathrm{kg} / \mathrm{m}^{3}\right)$ was calculated by ratio of cylinder mass, filled with powder $\left(\mathrm{P}_{\mathrm{n}}+\mathrm{n}, \mathrm{kg}\right)$ and empty cylinder $(\mathrm{n}, \mathrm{kg})$ to the cylinder volume after succession $\left(\mathrm{V}, \mathrm{m}^{3}\right)$, using formula (4):

$$
P=\frac{\left(P_{n}+n\right)-n}{V}
$$

Testing allowed us to determine using specified criteria, the bulk density and tapped density of the material, which consists of solid particles (powders) to compaction, aptness of material to compaction, as well as its volume and density after compaction (Hryzodub et al., 2015).

Tablets' test was conducted according to modern requirements (according to division 2.9.3 of SFU, Hryzodub et al., 2015).

Tablets' disintegration was conducted from the weighted amount $0.5 \mathrm{~g}$ according to SFU using the sieve with 2.0 and $0.5 \mathrm{~mm}$ meshes. However, when performing "Dissolve" test Pharmacopeia does not require the obligatory "Disintegration” test (Hryzodub et al., 2015).

Determination of hardness was conducted using TVT of "Erweka" apparatus (Germany) according to modern requirements (according to division 2.9.8 of SFU, Hryzodub et al., 2015).

Determination of friability was conducted using TAP "Erweka" tester on $25 \mathrm{rmp}$ for $5 \mathrm{~min}$ (2.9.7, Hryzodub et al., 2015). 20 preweighted tablets were loaded into the drum. Friability index (C, \%) was determined by ratio of difference between tablets' mass before abrasion $(\mathrm{P}, \mathrm{g})$ and after abrasion $(\mathrm{Pk}, \mathrm{g})$ to tablets' weight value before abrasion (P, g), using formula (5):

$$
C=\frac{P-P_{k}}{P} x 100 \%
$$

The granules' moisture content was determined as loss on drying. The determination was conducted using type UV-1 express-moisture meter. Sample moisture content (X, \%) was calculated as the ratio of the difference between the weight of the sample for testing $\left(\mathrm{P}_{\mathrm{o}}, \mathrm{mg}\right)$ and the sample's constant weight after complete desiccation ( $\mathrm{P}, \mathrm{mg}$ ) to the index of the sample for testing $\left(\mathrm{P}_{\mathrm{o}}, \mathrm{mg}\right)$, using formula (6):

$$
X=\frac{P_{0}-P}{P_{0}} \times 100 \%
$$

The research was conducted in 5 laboratory samples by the methods described above. The data in the tables is given in the form $\mathrm{x} \pm$ $\mathrm{m}$, where $\mathrm{x}$ is the average value of the indicator, $\mathrm{m}$ is the reliable interval at the level $\mathrm{P}<0,05$; the results obtained were considered statistically significant (Gubler \& Genkin, 1973; Mincer et al., 1991; Pashev et al., 2009). We used an ANOVA, the basic principles of which are developed in the scientific papers Lapach (2002), Kobzar' (2006). Authors of this article analysed selected monographs and research methods on powdered and tableted substances, which are presented in Ph. Eur. 8.8 (2014).

\section{Results}

A biotechnological method for obtaining biomass of basidial fungi (Basidiomycetes) used both as a biologically active substance and as 
further development of broad-spectrum pharmaceuticals was developed for the first time. A deep cultivation method, adapted to the raw plant material base of Ukraine, was used. Malt wort without hops (Humulus lupulus, Cannabaceae) was used as a nutrient medium - a product of soaked and germinated seeds of cereal cultures preheated at a certain temperature, which contributed to the enzymatic destruction of starch in the malt seed and the formation of sugar, mainly maltose. Preclinical studies of specific activity showed a steady increase in human immune status. This confirmed the feasibility of evaluating the properties of the specified biosystem and possible further development of an appropriate fungal therapeutic drug with immunomodulatory and antitumor action.

For the purpose of balanced formula development and industrial technology of a new local tabloid form medicated product codenamed "Shytavit", it was necessary to define and substantiate the sequence of in-process production stages and its pivotal points. This task was completed based on experimental research, conducted using the above mentioned methods. It is commonly known that the production of pills starts with research on the parent's drug properties, which considerably preordain tableting short-cut, selection of available auxiliary substances, which induces the necessary quality of the mentioned formulated product (Dmitrievskij, 2008). Each of factors mentioned above has its certain effect on the pharmacologically active substance. Bulk material in the form of powder-like forms (particle size up to $0.2 \mathrm{~mm}$ ) or granular (correspondingly $0.1-3.0 \mathrm{~mm}$ ) is used as the output raw material. They have certain physical, chemical, structural-mechanical and technological properties. In particular, technological properties include flowability, ability to compress, tapped density (mass), fractional (granulometric) composition, moisture content, dispersion, etc. (Gladuh et al., 2016).

At the initial research phase, physicochemical properties of the primary biologically active substance were explored: Shiitake fungi dry powder, its dispersity degree was determined using the sieve method. It is known that the abovementioned properties of the pharmaceutical powder are induced by its crystallographic structure, that is why the shape of L. edodes particles was determined first (Fig. 2).

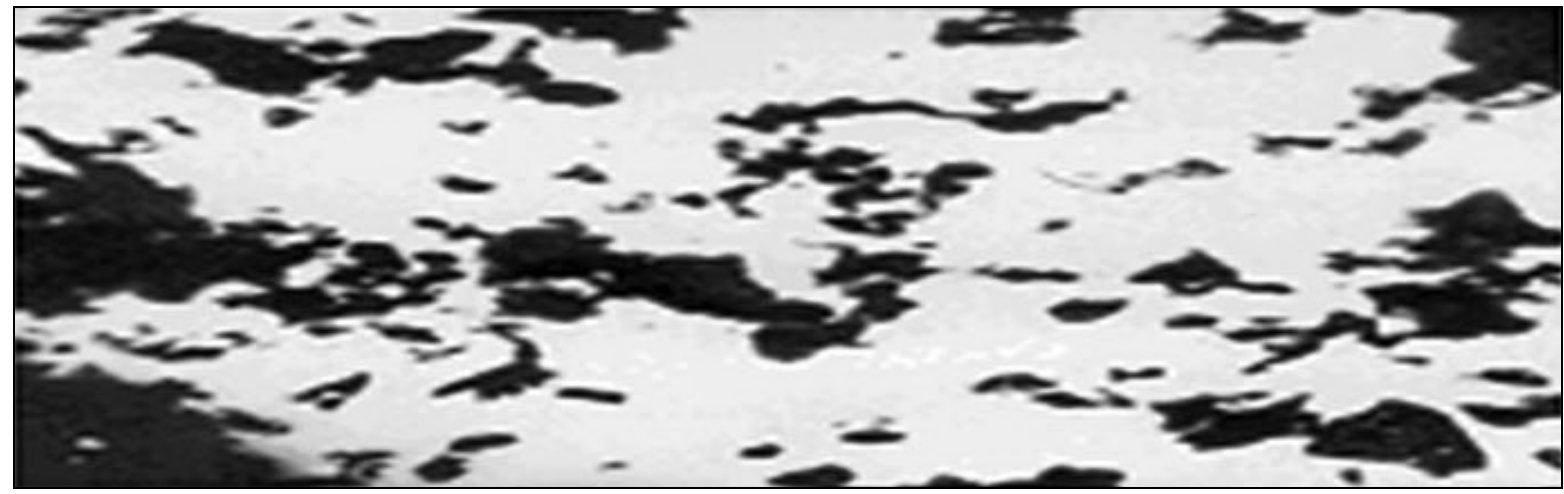

Fig. 2. Microcrystalline structure of L. edodes: the image of the object was obtained using MBI-15 electronic microscope (with 200 ${ }^{\mathrm{x}}$ magnification) and captured by the camera Sony CCD-IRIS; staining of the fungus biomass samples (in particular, using Lugol' solution) was not performed; in this case, the polysaccharides will react with the micropowder, leading to the change of colour, which is undesirable

Crystallographic analysis of the microcrystalline structure of the powdered target under $200^{\mathrm{x}}$ magnification showed that it is a mediumdispersed powder with a cuboidal crystalline form with rough and coarse particles surface.

Analysis of the fraction composition of various substances series shows the powder's cryptocrystalline structure with the isodiametric shape of grains (in the form of shapeless lumps), the major portion of which (>90\%) had less than 10 microns (Table 2). Based on the obtained data, we can assume that due to the fact that Shiitake fungi biomass dry powder has an isodiametric particles structure, it may have a good flowability. However, to confirm this assumption it was necessary to research its technological characteristics (Pashev et al., 2010). The results of technological characteristics research on all 5 samples of the presented target showed relative stability of all test parameters in laboratory samples.

Table 2

Fractional composition study results of dry powder biomass batches of Shiitake fungus taken as main biologically active substance

\begin{tabular}{lccccc}
\hline \multirow{2}{*}{ Series number } & \multicolumn{5}{c}{ Particles mass percentage, \% } \\
\cline { 2 - 6 } & $<40 \mu \mathrm{m}$ & $<20 \mu \mathrm{m}$ & $<10 \mu \mathrm{m}$ & $<5 \mu \mathrm{m}$ & $<1 \mu \mathrm{m}$ \\
\hline Series 1 & 1 & 8 & 17 & 58 & 16 \\
Series 2 & 1 & 9 & 18 & 55 & 17 \\
Series 3 & 4 & 9 & 21 & 51 & 15 \\
Series 4 & 4 & 12 & 18 & 52 & 14 \\
Series 5 & 5 & 5 & 24 & 48 & 18 \\
Average value & 2.5 & 8.6 & 19.6 & 52.8 & 16.0 \\
\hline
\end{tabular}

In the second stage of the research, we tried certain excipients and assessed technological characteristics of Shiitake fungus biomass for the purpose of its possible tableting (Gladuh et al., 2016; Rybachuk et al., 2016). Scientifically proven selection of excipients in each particular case is one of the key factors in obtaining tabloids with maximum therapeutic activity and minimal adverse drug reaction. With the purpose of improvement of the technological parameters of Shiitake fungi biomass dry powder, the following excipients were used: Potato Starch (Solani Amylum), Aerosil (Silica) and Magnesium stearate (Magnesii stearas). At the mixing stage for tableting, the following technological characteristics were evaluated: flowability, compression capability, and tapped density (Table 3).

Table 3

Results of technological characteristics of the Shiitake fungus biomass samples for tableting

\begin{tabular}{|c|c|c|c|c|c|}
\hline No & $\begin{array}{c}\text { Mixture } \\
\text { composition }\end{array}$ & $\begin{array}{l}\text { Proportion of } \\
\text { ingredient, \% }\end{array}$ & $\begin{array}{c}\text { Flowability, } \\
\mathrm{kg} / \mathrm{s}\end{array}$ & $\begin{array}{l}\text { Direct comp- } \\
\text { ression N, H }\end{array}$ & $\begin{array}{c}\text { Tapped } \\
\text { density, } \mathrm{kg} / \mathrm{m}^{3}\end{array}$ \\
\hline 1 & $\begin{array}{l}\text { DPSF }^{*} \\
\text { Starch }\end{array}$ & $\begin{array}{l}80 \\
20\end{array}$ & $2.81 \pm 0.14$ & $62.0 \pm 3.2$ & $0.48 \pm 0.04$ \\
\hline & DPSF & 80 & \multirow{3}{*}{$3.15 \pm 0.10$} & \multirow{3}{*}{$59.0 \pm 2.5$} & \multirow{3}{*}{$0.44 \pm 0.02$} \\
\hline \multirow[t]{4}{*}{2} & Starch & 19 & & & \\
\hline & Aerosil & 1 & & & \\
\hline & DPSF & 80 & \multirow{5}{*}{$3.61 \pm 0.20$} & \multirow{5}{*}{$54.1 \pm 2.5$} & \multirow{5}{*}{$0.46 \pm 0.02$} \\
\hline & Starch & 16 & & & \\
\hline \multirow[t]{3}{*}{3} & Aerosil & 1 & & & \\
\hline & \multirow{2}{*}{$\begin{array}{l}\text { Magnesium } \\
\text { Stearate }\end{array}$} & \multirow{2}{*}{3} & & & \\
\hline & & & & & \\
\hline & DPSF & 85 & & & \multirow{4}{*}{$0.52 \pm 0.02$} \\
\hline & Starch & 11 & \multirow{3}{*}{$3.51 \pm 0.17$} & \multirow{3}{*}{$51.0 \pm 2.6$} & \\
\hline \multirow[t]{4}{*}{4} & Aerosil & 1 & & & \\
\hline & Magnesium & 3 & & & \\
\hline & $\begin{array}{l}\text { Stearate } \\
\text { DPSF }\end{array}$ & 85 & \multirow{5}{*}{$3.40 \pm 0.16$} & \multirow{5}{*}{$49.1 \pm 2.3$} & \multirow{5}{*}{$0.57 \pm 0.04$} \\
\hline & Starch & 10 & & & \\
\hline \multirow[t]{3}{*}{5} & Aerosil & 2 & & & \\
\hline & Magnesium & 3 & & & \\
\hline & Stearate & & & & \\
\hline
\end{tabular}

Notes: * - DPSF - Shiitake fungi biomass dry powder, ** - the number of measurements $\mathrm{n}=5, \mathrm{P}=95 \%$, $* * *$ - system intemational units of measurement were used. 
During the third stage we conducted a selection of a possible method of Shiitake fungi biomass dry powder tableting, in particular, we analysed the practicability of conducting a direct compression or the necessity of applying pre-granulation. The results of tablets' direct compression impact and their quality are shown in Table 4. During the fourth stage, a tailored composition of tablets was defined under the codename "Shytavit", the external characteristics of which would ultimately meet the compendial requirements (Table 5).

Table 4

Results of qualitative indicators of tablets obtained by direct compression

\begin{tabular}{|c|c|c|c|c|c|}
\hline Index & Mixture 1 & Mixture 2 & Mixture 3 & Mixture 4 & Mixture 5 \\
\hline Weight variation, \% & $8.0 \pm 0.40$ & $8.4 \pm 0.40$ & $8.3 \pm 0.50$ & $7.9 \pm 0.40$ & $8.2 \pm 0.50$ \\
\hline Disintegration time, min & $4.9 \pm 0.30$ & $5.1 \pm 0.30$ & $5.0 \pm 0.20$ & $5.2 \pm 0.30$ & $5.3 \pm 0.40$ \\
\hline Abrasion, \% & $16.0 \pm 0.30$ & $15.5 \pm 0.07$ & $15.0 \pm 0.40$ & $14.0 \pm 0.30$ & $15.0 \pm 0.40$ \\
\hline
\end{tabular}

Notes: the number of measurements $\mathrm{n}=5$.

Table 5

Results of qualitative and quantitative composition of raw materials for further tableting

\begin{tabular}{lcccc}
\hline \multicolumn{1}{c}{ Ingredients' Weight } & Sample 1 & Sample 2 & Sample 3 & Sample 4 \\
\hline DPSF, g & 0.5000 & 0.5000 & 0.5000 & 0.5000 \\
Aerosil, g & 0.0150 & 0.0150 & 0.0150 & 0.0150 \\
Starch, g & 0.0800 & 0.1690 & 0.0567 & 0.0275 \\
Purified water, g & - & 0.2300 & - & - \\
Starch solution, 5\%, ml & - & 0.2510 & - & - \\
Starch solution, 10\%, ml & - & - & 0.2630 & - \\
Starch solution, 20\%, ml & - & - & - & 0.0716 \\
Magnesium Stearate, g & 0.0050 & 0.0050 & 0.0050 & 0.1880 \\
\hline
\end{tabular}

Notes: the number of measurements $\mathrm{n}=5$; in some cases, not all ingredients were used for mixtures (marked with a dash in the table).

At the final stage of the work, the impact of tableting mass moisture effect on the compressing process and the tablets' quality was investigated (Tables 6, 7). The drying of the tableting mass of Sample 2 was performed at a constant temperature.

\section{Table 6}

Impact of tableting mass moisture effect on compressing process and tablets' quality

\begin{tabular}{ccccl}
\hline $\begin{array}{c}\text { Granules } \\
\text { moisture } \\
\text { content, \% }\end{array}$ & $\begin{array}{c}\text { Granules } \\
\text { flowability, } \\
\mathrm{kg} / \mathrm{s}\end{array}$ & $\begin{array}{c}\text { Tablets } \\
\text { hardness, }\end{array}$ & $\begin{array}{c}\text { Tablets } \\
\text { dintegration, } \\
\text { min }\end{array}$ & \multicolumn{1}{c}{$\begin{array}{c}\text { Characteristics } \\
\text { of obtained samples }\end{array}$} \\
\hline 40.0 & 2.7 & 35 & 1.0 & Agglutination of tablets \\
25.0 & 2.9 & 42 & 1.5 & Agglutination of tablets \\
8.0 & 3.2 & 48 & 2.0 & $\begin{array}{l}\text { Slight agglutination of tablets } \\
3.5\end{array}$ \\
3.1 & 3.4 & 60 & 2.0 & $\begin{array}{l}\text { Satisfactory appearance of } \\
\text { tablets appearance }\end{array}$ \\
3.0 & 59 & 2.1 & Slight agglutination of tablets \\
\hline
\end{tabular}

Table 7

Variation of the tablets' samples main quality indicators $(n=5)$

\begin{tabular}{lccccc}
\hline \multicolumn{1}{c}{ Attributes } & Sample 1 & Sample 2 & Sample 3 & Sample 4 & Sample 5 \\
\hline Flowability, kg/s & 3.9 & 3.4 & 2.3 & 2.0 & 3.2 \\
Disintegration, min & 1.3 & 2.0 & 3.5 & 5.6 & 1.7 \\
Hardness, H & 45.0 & 62.0 & 88.0 & 110.0 & 51.0 \\
Friability, \% & 5.0 & 0.2 & 0.3 & 0.3 & 4.0 \\
\hline
\end{tabular}

Considering test results, it was established that the quality of tablets of the provided formulation and the stipulated process technology under the codename "Shytavit" best meets the compendial requirement .

\section{Discussion}

Expanding the range of highly effective medicines for the treatment of a number of diseases is of paramount importance in the medical care of the population. The solution to this problem is facilitated by the search and introduction of new original medicines, the development of scientifically sound technology for their manufacture, based on the latest advances in science and technology. Despite a sufficient number of highly effective modern drugs of synthetic origin, the interest in natural biosystems is not diminished. The problem of the creation of domestically produced medicines based on fungus, with a pronounced pharmacotherapeutic activity, simple manufacturing technology, which are non-toxic in comparison with chemical synthesis products used for immunocorrection therapy, is very relevant for Ukraine. Immune dysfunctions, autoimmune conditions, cancer diseases are clearly the leaders among the causes of death both among the Ukrainian population and on a planetary scale. The Basidiomycetes Shiitake fungus (L. edodes) is considered as a unique biological system with a clearly expressed ability to be included in the regulatory mechanism of human immunomodulation. This is confirmed both by literary studies and by our own research results (Pashnev et al., 2010; Shah et al., 2011; Ren et al., 2012; Welbaum, 2015; Drori et al., 2016; Krasnopol'skaya et al., 2016).

Today, the pharmaceutical market is gradually beginning to offer a variety of dosage forms based on biologically active substances, isolated from this fungus. However, most of them, till now have been the product of a simple processing of touchwood and spawn (sometimes together with substrate): extracts, tinctures (water or oil), infusions, ointments, balms, cognac tincture, vodka tincture or flaxseed oil infusion of Linum usitatissimum), solutions (1 mg/bottle), drops, capsules, suppositories, powder, syrup, saps. Furthermore, it is a plant product for many biologically active dietary supplements (Sotnikova, 2001; Pashnev et al., 2010; Bisen et al., 2010; Taufiqur, 2012; Giavasis, 2014; Drori et al., 2016; Krasnopol'skaya et al., 2016). For example: "Shiitake mushroom extract No. 40" in the form of capsules and tablets $0.25 \mathrm{~g}$, No. 40 (production of Ukraine); "Shiitake mushroom extract No. 80" in the form of capsules and tablets 0.25 g, No. 80 (Ukraine); "Immunomax" represents freeze-dried powder in ampoules and vials of 100 or 200 IU (Finland); "Fungimax" tablets of $0,4 \mathrm{~g}$ No. 30 in the form of capsules, $0.2 \mathrm{~g}$ No. 60 or in powder form in bags of $1.0 \mathrm{~g}$ (Russia); "Shiitake" represents tablets with a skin of 0.56 g No 20 and No. 60 (Russia); "Mushroom triple” (drug fungus Shiitake, Reishi and Maitake) represents tincture at 250,0 g (Russia); "Shiitake Fung Chi” in the form of capsules, $75 \mathrm{mg}$ No. 60, cream in tubes of $50 \mathrm{mg}$ of powder in bags No. 30 (Russia), etc. Clear recommendations regarding the use of these drugs were suggested. For example, the cream "Shiitake FungChi" is designed for external use in diseases of the joints, oncology (in cases of metastasis to bone tissue), ulcers and wounds that are difficult to heal, benign formations on the skin (papillomas, lipomas, warts).

To achieve the goal of this research in the course of theoretical and experimental study of the mechanism of operation of the polysaccharide Shiitake fungi complex on the immune system of tissue of the human large intestine, we reached the conclusion that the most effective is the usage of a micro powder obtained from the touchwood of Shiitake fungi, rather than, for example, its extract or an extract from its kames. According to data from the literature, there is a direct proportion between the length of glycan in medication and intensity of its effect on immune cells. On the other hand, molecules in extracts are short. In those cases when it is necessary to use $1-2 \mathrm{~g}$ in conversion to Shiitake extract to reach the desired effect, only $200 \mathrm{mg}$ of the micro pow- 
der is enough (Malitikov, 2013). Consequently, a medicinal product based on the said powdered biologically active substance, shows more apparent therapeutic benefit and is economically more affordable.

In our view, the optimal tableting technologies of Shiitake micro powder have still not been fully examined. A detailed survey in this field may contribute to the emergence of highly effective tableted immunocorrecting drugs for prevention and complex therapy of immune diseases.

The choice of the dosage form (Tabulettae) relates to a number of its known advantages (medical pharmaceutical, manufacturing, operational) and high bioavailability when used orally (per os). This leads to the increase of worldwide production of tabloids by $10-15 \%$ annually (Gladuh et al., 2016). Occasional studies have been dedicated to the topic of development of $L$. edodes based tableted forms. In particular, according to Feofilova (2004), tablets were produced from the dry extract of these fungi. Dry concentrate contained sufficiently high percentage of BAS, including lentinan, the anti-tumour effect of which depended heavily on the dose. Based on the results of the preclinical studies, the recommended therapeutic dose of the dry Shiitake extract was 2.0 in one pill, and 2-4 pills were to be taken daily. The pills provided were covered with the special soluble (sugar) coating (Feofilova, 2004). Some manufacturers added vitamins, for example, $D_{3}$ (Cholecalciferol) and C (Ascorbic acid), medicinal herbs like redberry (Panax schinseng, Araliaceae). The abovementioned studies intended the development of biologically active substances only, as noted above. We did not find any publications devoted to the development of tablets on the basis of Shiitake fungus powder.

Our studies were aimed to the development of a pharmaceutical drug of pluripotential treatment-and-prophylactic action. Theoretical and experimental confirmation of the tailored composition and technology of the tablets codenamed "Shytavit" included the analysis of physicochemical and technological properties of the ingredients. The choice of excipients was determined primarily based on physicochemical and technological properties of BAS and environmental stability factors. Biopharmaceutical studies prove that excipients are not form-building vehicles, but have multiple impacts on the pharmaceutical drug and its therapeutic effect (Dmitrievskij et al., 2010). In particular, the conditions for a direct compression of tablet formulation have been investigated, and the influence of the type and concentration of binders and lubricants on compressibility and the quality of the tablets obtained have been previously studied. The optimal concentrations of binders and the force of tablet compression have been determined (Rybachuk \& Rybachuk, 2016). One of the problems of drug manufacturing is how to obtain satisfactory powder flowability in tableting machine feeders (hoppers, batchers). Obtained granules or powder have an irregular surface, which hinders its absorption from the hopper to the matrixing cavity. Moreover, granules can stick to the walls of the matrix and punches as a result of adhesion in contact areas of the particles in tablet tooling. To minimise such adverse effects, friction-proof substances, presented by the glidant and lubricants, are used (Gladuh et al., 2016).

In view of the above, the following excipients (in this case friction proof substances, lubricants) of the pharmaceutical composition (tabletting mass) were chosen:

- Aerosil (Silicii dioxydum, Aeroperl) as glidant substance, the quantity of which cannot exceed $10 \%$ of the whole mass;

- Amylum Solani (Potato starch) as glidant and anti-adherent substance the quantity of which is not regulated by the State Pharmacopoeia of Ukraine;

- Magnesii stearas as a glidant, lubricant, and anti-adherent substance, the quantity of which cannot exceed $1 \%$ of the whole mass (Hryzodub et al., 2015).

The quality of the above mentioned is subject to special conditions stipulated in European Pharmacopoeia, in particular, Aerosil Ph. Eur. Monograph 0434 EФ 6 2.9.2, Magnesii stearas Ph. Eur./E572 Monograph ЕФ 7 2.6.8, 2.6.14 (Ph. Eur., 2014).

Excipients must provide their necessary functional properties under minimum content with minimal content in the product. In this regard, empirically, a certain content of each mentioned ingredient was matched to achieve the optimal technological characteristics of tableting mass with Shiitake fungi biomass dry power. In our view, Series No.4 has the best ratio of ingredients in tableting mass (Table 2), namely: the amount of dried and ground biologically-active substance of $L$. edodes is $85 \%$, Solani amylum (Potato starch) is $11 \%$, Magnesii stearas (Magnesium stearate) is $3 \%$ and Silicii dioxydum (Aerosil, Aeroperl) is $1 \%$. Such amounts are consistent with the requirements of Pharmacopeia.

Technological development always requires appropriate scientifically based technological schemes of production. With the development of biopharmaceutics, more attention is being paid to the technological aspects of the drug formulation. Choice of tableting method is the critically important task for $L$. edodes dry powder based drug technology development in the form of pills. As the analysis of the literature showed, research in this direction continues. For example, in the article by Rybachuk (2016) the technology of manufacturing tablets by direct compression of natural zeolite is described (Rybachuk \& Rybachuk, 2016). Without a doubt, a major pragmatic interest is the production of directly compressed tablets, as it allows high production efficiency to be achieved and shortens the time of technological processes through excluding some technological operations. It is known that the capacity for direct compression (without granulation) is typical, first of all of the substances which belong to the cubic system (Dmitrievskij et al., 2010). The object of our study possesses precisely such characteristics (medium dispersed powder of cubic crystalline form), as described in the Results section. Furthermore, powdery substances with the abovementioned physicochemical properties are able to be tableted directly without such auxiliary excipients as Sodium chloride and Potassium bromide (Gladuh et al., 2016).

However, the quality of all tablet samples, obtained using the abovementioned method, appeared unsatisfactory (Table 2), namely: (a) on simple examination we noticed contaminations and the surface of all tablet samples was not unscored; (b) during the tableting process the tableting mass of sampled No. 2 and No. 4 stuck to the tablet tooling and the obtained tablets had irregular edges; (c) obtained tablet samples did not pass the friability test and mass deviation indicator according to the requirements of SPU. All of the above-mentioned factors impelled us to reject the direct extrusion method.

For further study, we proposed a pre-granulation method for powder compaction and obtaining uniform crystal granules which have to improve the flowability and the appearance of tablets. Since we are using BAS as an active substance, we chose the method of wet granulating, which implies obtainment of granules with the possibility of short-term contact of $L$. edodes dry powder with granulating liquid and adjustable temperature scenario. It is worth mentioning that in the process of "Shiitake Mushroom Powder" drug production in tablets of $0.4 \mathrm{~g}$, developed by State Chemical-Pharmaceutical Academy (St. Petersburg, Russia), these medicinal fungi were not cooked/heated at all. This ensured the preservation of polysaccharides in its native state (Malitikov, 2013).

We propose a production technology of the medicinal product, which also allows preservation of all BAS of the provided materials. More specifically, the granulate was prepared with the pre-sifted powders of Shiitake, starch, aerosol and magnesium stearate. Purified water, as well as $5 \%, 10 \%$ and $20 \%$ of starch paste, were used as humectants. The humectant was calculated on the basis that the water is $44 \pm 1 \%$. This refers to the fact that if the concentration of the moisturiser is less than $38 \%$, granulated structure is not observed and at the concentration of $46 \%$ and more, adhesion of the granulate takes place.

Based on the obtained measured data (Tables 2, 4) the optimal formulation of the product in tablet form under the codename "Shytavit" was determined: Shiitake fungi biomass dry powder $-0.4 \mathrm{~g}$, Aerosil $-0.015 \mathrm{~g}$, Starch $-0.08 \mathrm{~g}$, Magnesium stearate $-0.0005 \mathrm{~g}$ per tablet. The resulting tablets with mentioned qualitative-quantitative formula complied with pharmacopeia requirements for its terminal characteristics.

Consequently, with the flowability of 3.4-3.5 kg/s, compression capacity $51.0 \mathrm{H}$ and tapped density $0,52 \mathrm{~kg} / \mathrm{m}^{3}$, the highest accuracy of the dose delivery was achieved for tablets for feeder units of the tableting machine (under observance of the Shiitake fungus biomass storage regulations). 
Obviously, the quality of tablets is significantly affected also by the granules moisture index, which ensures the necessary flowability of the powder or tableting mass. Excessive moisture content of the powder decreases its flowability through forming the adsorbed layer on the particles. Therefore, the tableting material has to have optimal moisture. There is a positive correlation between the given moisture of the tableting mass and its compression capacity. The better the compressibility, the higher the hardness of the tablet. If the compressibility is low, the tablet will tend to partial or event full collapsibility when stripping off the tableting machine matrix (Gladuh et al., 2016).

The moisture content of the powders used in tablet production must be between 3-5\% (Dmitrievskij et al., 2008). The tableting mass (3.5\%) moisture content determined by us, also proves that the selected experimental formulation agents the high quality of tablets (Tables 5, 6). Analysis of $L$. edodes processability discovered marginal moisturesorptive properties and medium flowability.

The set of studies conducted by us showed that physicochemical and technological properties of Shiitake fungi biomass dry powder comply with the requirements for powders which can be tableted using the pre-granulation method (with the possibility of the short-term contact of $L$. edodes dry powder with a liquid for granulation along with adjustable temperature) without adding auxiliary excipients (Sodium chloride and Potassium bromide), which shortens the time of the technological process and lowers the product cost.

With this in mind, Shiitake fungus according to analysis of the literature is currently the most superpotent innovative plant-based medication with immunomodulatory effect. Todays scientists are using the protective properties of $L$. edodes more often ,combining it with chemo- and radiation therapy. By dint of such fungi based medicines, patients even with stage II-III cancer can reach remission from three months to 10 years (when combined with the traditional cancer treatment) (Shen et al., 2011; Giavasis, 2014; Meng et al., 2016; Zhang et al., 2016). In addition, Shiitake remains one of the most biologically active non-hazardous fungi.

The tabletted Shiitake fungi biomass dry powder based therapeutic developed by the authors of this article is a highly effective drug, which, with no doubt will enrich the domestic pharmaceutical market. Even in the absence of treatment indication (immune dysfunction, including AIDS, oncology diseases, autoimmune and neurological diseases, ecological allergies, mycotic and virus infections, multiocular sclerosis, post-infarct and post-apoplectic conditions, vascular diseases, viral upper respiratory tract infection), it is recommended to take "Shytavit" tablets twice per year as a preventive measure, in spring and in autumn, when the human immune system is most vulnerable and requires help from the outside. It is worth mentioning that "Shytavit" tablets work well with most nutraceuticals and potentiate the effect of medicinal herbs. Exceptions are Echinaceae (Asteraceae) and Aconitum napellus (Ranunculaceae). It is not recommended to combine fungi therapy with ASA (Aspirin).

The foregoing shows that the dried biomass of $L$. edodes is a prospective product for developing pharmaceutical drugs and is capable of significantly strengthening human immune defences.

\section{Conclusion}

Based on examination of the literature , we explored the main tendencies of pharmacological mycology development, in particular with regard to Shiitake (L. edodes). We conducted a comparative assessment of other mushrooms, champignons (Agaricus bisporus) and Lingzhi fungus (Ganoderma lucidum). We consider the evaluation of technological properties of Shiitake fungi with the purpose of the further potential development of a convenient immunomodulation medicine drug to be of current interest.

We researched and presented the relationship between the strong correlation between the chemical makeup of $L$. edodes powdered biomass, as research target, and its pronounced immunomodulation and antitumor effect with application of modern methods of scientific analysis. A biotechnological method of Basidionycetes biomass production was developed for the first time. The deep cultivation method, adapted by the authors to Ukraine's plant resource base, was used. Preclinical studies confirmed an increase inf patients' immune status.

The literature review did not found publications on the development of tableted drugs using Shiitake fungi powder basis. Previous researchers focused only on development of nutritional supplements. One may assume that the authors are the initiators of research in the abovementioned direction, as the search for the optimal technology for micropowder tableting of this biosystem was conducted for the first time.

Based on the research undertaken , we proposed a technology of tablets under the codename "Shytavit", as well as a theoretical and experimental proven integrated approach to its formulation:

- we provided the reasons for preference for the tableted form as the most optimal in the given case, as well as rationale for tableting;

- we outlined physical and chemical parameters of Shiitake fungi biomass dry powder as working quality indexes (crystallographic property and fractional makeup), which induce the ability for compression;

- based on the technological research findings (flowability - 3.40$3.51 \mathrm{~kg} / \mathrm{s}$, compressibility $-51 \mathrm{H}$, tapped density $-0,52 \mathrm{~kg} / \mathrm{m}^{3}$, moisture content $-3.5 \%$ ) we substantiated the possibility of tableting of dried powder of Shiitake fungus biomass with the use of antifriction excipient only;

- the direct compression method was rejected as a result of the unsatisfactory quality of all tables samples;

- we selected tableting technology with the use of pre-granulation, with the possibility of short-term contact of the $L$. edodes dry powder with granulating liquid and adjustable temperature scenario;

- we determined the optimal qualitative-quantitative formula of the medicine per tablet (Shiitake fungi biomass dry powder $-0.4 \mathrm{~g}$, Aerosil $0.015 \mathrm{~g}$, potato starch $-0.08 \mathrm{~g}$, and magnesium stearate $-0.005 \mathrm{~g}$ ), which is in full compliance with compendial requirements.

The authors developed a new tableted drug codenamed "Shytavit" with tablet strength $0.5 \mathrm{~g}$ for fungi therapeutic correction of immune dysfunctions, the production technology of which ensures the presservation of all biologically active properties of the raw material in its original condition.

\section{References}

Babickaya, V. G., Chemook, T. V., Shcherba, V. V., Puchkova, T. V., Filimonova, T. V., \& Osadchaya, O. V. (2009). Harakteristika lipidov glubinnogo miceliya gribov [Characteristics of deep mycelial lipids of mushrooms]. Visnyk of Minsk Gosudarstvennogo Universiteta, 4(1), 154-158 (in Russian).

Bisen, P. S., Baghel, R. K., Sanodiya, B. S., Thakur, G. S., \& Prasad, G. B. (2010) Lentinus edodes: A macrofungus with pharmacological activities. Current Medicinal Chemistry, 17(22), 2419-2430.

Dmitrievskij, D., Boguslavs'ka, L., Hohlova, L., Bobrickaya, L., Spiridonov, S. Vinnik, L., \& Rybachuk, V. (2008). Tehnologija likars'kyh preparativ promyslovogo vyrobnyctva [The technology of medicinal preparations of industrial production]. Nova Kniga, Vinnica. pp. 177-214 (in Ukrainian).

Dmitrievskij, D., Rybachuk, V., Homenko, V. Gudzenko, O., Kotenko, O., \& Maslij, Y. (2010). Dopomizhni rechovyny v tehnologii likiv: Vplyv na thenologichni, spozhyvchi, ekonomichni kharakterystyky i terapevtychnu efektyvnist' [Excipients in pharmaceutics: Impact on technological, consumer, economic characteristics and therapeutic efficiency]. Zoloti Storinki, Har'kiv. pp. 410-417 (in Ukrainian).

Drori, A., Shabat, Y., Ben, Y. A., Danay, O., Levanov, D., Zolotarov, L., \& Ilan, Y. (2016). Extracts from Lentinula edodes (shiitake) edible mushrooms enriched with vitamin D exert an anti-inflammatory hepato-protective effect. Journal of Medicinal Food, 19(4), 383-389.

European Pharmacopoeia 8.0. Edition 8. Council of Europe, Strasbourg.

Feofilova, E. P. (2004). Micelial'nye griby kak istochniki polucheniya novyh lekarstvennyh preparatov s immunomoduliruyushchej, protivoopuholevoj i ranozazhivlyayushchej aktivnost'yu [Mycelial mushrooms as sources of new medicinal preparations with immunomodulating, antitumor and wound healing activity]. Immunopatologiya, Allergologiya, Infektologiya, 1, 27-32 (in Russian).

Friedman, M. (2016). Mushroom polysaccharides: Chemistry and antiobesity, antidiabetes, anticancer and antibiotic properties in cells, rodents and humans. Foods, 5(4).

Ganeshpurkar, A., Rai, G., \& Jain, A. P. (2010). Medical mushrooms: Towards a new horizon. Pharmacognosy Reviews, 4(8), 127-135. 
Gladuh, Y. V., Sajko, I. V., Sichkar', A. A., \& Soldatov, D. P. (2016). Teoreticheskie osnovy farmacevticheskoj tekhnologii [The theoretical basis of pharmaceutical technology]. NFAU, Har'kov (in Russian).

Giavasis, L. (2014). Bioactive fungal polysaccharides as potential functional ingredients in food and nutraceuticals. Current Opinion in Biotechnology, 2014, 162-173.

Gubler, E. V., \& Genkin, A. A. (1973). Primenenie neparametricheskih kriteriev statistiki v mediko-biologicheskih issledovaniyah [Application of nonparametric statistics in biomedical research]. Medicina, Leningrad (in Russian).

Hearst, R., Nelson, D., McCollum, G., Millar, B. C., Maeda, Y., Goldsmith, C. E., Rooney, P. Y., Louqhrey, A., Rao, J. R., \& Moore, J. E. (2009). An examination of antibacterial and antifungal properties of consituents of Shiitake (Lentinus edodes) and Oyster (Pleurotus ostreatus) mushrooms. Complementary Therapies in Clinical Practice, 15(1), 5-7.

Hryzodub, O. I. (Ed.). (2015). Derzhavna farmakopeya Ukrainy [State pharmacopoeia of Ukraine]. Derzhavne pidpryemstvo "Ukrayins'kiy naukoviy farmakopeyniy tsentr yakosti likars’kykh zasobiv”, Har'kiv (in Ukrainian).

Il'inskih, N. N., Gluhova, L. B., Il'inskih, E. N., \& Karnachuk, P. A. (2012). Citologicheskie i citogeneticheskie izmeneniya T-limfocitov krovi cheloveka pri vozdejstvii protivoopuholevogo preparata Adriamicina na fone vvedeniya ehkstraktov iz miceliya gribov Shiitake (Lentinula edodes) v usloviyah in vitro [Cytological and cytogenetic changes in human T-lymphocytes under the influence of the antitumor drug Adriamycin against the background of the introduction of extracts from the mycelium of the mushrooms of Shiitake (Lentinula edodes) under in vitro]. Vestnik Tomskogo Gosudarstvennogo Universiteta, 356, 171-175 (in Russian).

Jones, K. (1995). Shiitake. The healing mushroom. Healing Arts Press Rochester, Vermont.

Kobzar', A. I. (2006). Prikladnaya matematicheskaya statistika [Applied mathematical statistics]. Fizmatlit, Moskow (in Russian).

Krasnopol'skaya, L. M., Avtonomova, A. V., \& Yarina, M. S. (2016). Klinicheskie ispytaniya preparatov polisaharidov vyisshih gribov i vyibor dalneyshih putey ih ispolzovaniya [Clinical trials of polysaccharide preparations of higher fungi and the choice of further ways of using them]. Sbornik Nauchnyh Trudov. Moscow. pp. 487-491 (in Russian).

Lapach, S. N., Chubenko, A. V., \& Babich, P. N. (2002). Statistika v nauke i biznese [Statistics in science and business]. Morion, Kyiv (in Russian).

Lindequist, U., Niedermeyer, T. H. J., \& Julich, W. D. (2005). The pharmacological potential of mushrooms. Evidence-Based Complementary Altemative Medicine, 2(3), 285-299.

Malitikov, P. (2013). Shiitake protyv yazvy, gipertonii i skleroza [Shiitake versus ulcers, hypertension and sclerosis]. RIPOL Klassik, 9-15 (in Russian).

Meng, X., Liang, H., \& Luo, L. (2016). Antitumor polysaccharides from mushrooms: A review on the structural characteristics, antitumor mechanisms and immonomodulating activities. Carbohydrate Research, 424, 30-41.

Minato, K., \& Mizuno, T. (2001). Changes in immunomodulating activities and content of antitumour polysaccharides during growth of two mushrooms, Lentinus edodes (Berk.) Sing and Grifola frondosa (Dicks: Fr.) S. F. Gray. Intemational Journal of Medicinal Mushrooms, 3, 1-7.

Mincer, O. P., Ugarov, B. N., \& Vlasov, V. V. (1991). Metody obrabotki medicinskoj informacii [Methods of processing of medical information]. Vishha Shkola, Kyiv (in Russian).
Mizuno, T. A. (1997). Antitumor mushrooms - Ganoderma lucidum, Grifora frondosa, Letinus edodes, and Agaricus blazei. Gendai-Shorin, Tokyo.

Mizuno, T. A., \& Nishitani, Y. (2013). Immunomodulating compounds in Basidiomycetes. Journal of Clinical Biochemistry and Nutrition, 52(3), 202-207.

Pashnev, P. D., Bicko, N. A., Popovich, V. P., \& Fedoritenko, N. O. (2009). Matematicheskie metody planirovaniya ehksperimenta po vyrashchivaniyu biomassy griba Shiitake dlya dal'nejshego ispol'zovaniya v farmacevticheskoj promyshlennosti [Mathematical methods for planning an experiment on growing biomass of Shiitake mushrooms for further use in the pharmaceutical industry]. Zbomik Nauchnyh Trudov. Pyatigorsk. pp. 202-204 (in Russian).

Pashnev, P. D., Sjatinja, M. L., Popovich, V. P., \& Fedoritenko, N. O. (2010). Rozrobka tehnologiyi kapsul z suhim poroshkom biomasy grybiv Shiitake [Development of technology of capsules with dry powder of biomass of Shiitake mushrooms]. Farmacevtichnij Chasopis, 14, 44-46 (in Ukrainian).

Puchkova, T. A., \& Shcherba, V. V. (2006). Polisaharidy glubokogo miceliya i kul'tural'noj zhidkosti gribov Ganodrema lucidum i Lentinus edodes [Polysaccharides of deep mycelium and culture fluid of Ganodrema lucidum fungi and Lentinus edodes fungi]. Uspekhi Medicinskoj Mikologii, 1, 275-276 (in Russian).

Rao, J. R., Smyth, T. J., Millar, B. C., \& Moore, J. E. (2009). Antimicrobial properties of shiitake mushrooms (Letinula edodes). Journal of Antimicrobial Agents, 33(6), 591-592.

Ren, L., Perera, C., \& Hemar, Y. (2012). Antitumor activity of mushroom polysaccharides: A review. Food and Function, 3(11), 1118-1130.

Rybachuk, V. D., \& Rybachuk, D. V. (2016). Vyvchennya vplyvu dopomizhnykh rechovyn na presuyemist' poroshku tseolitu pryrodnoho [The study of the influence of auxiliary substances on pressing of zeolite powder natural]. Visnyk Farmatsiyi, Har'kov, 3, 13-17 (in Ukrainian).

Shah, S. K., Walker, P. A., Moore-Olufemi, S. D., Sundaresan, A., Kulkarmi, A. D., \& Andrassy, R. J. (2011). An evidence-based review of a Letinula edodes mushrooms extract as complementary therapy in the surgical oncology patient. Journal of Parenteral and Enteral Nutrition, 35(4), 449-458.

Shen, J., Jao, J., Tanida, M., Horii, Y., \& Nagai, K. (2011). An evidence-based perspective of Letinula edodes (Shiitake mushrooms) for cancer patients. In: Cho, W. C. S. (Ed.). Evidence-based anticancer materia medica. pp. 303-317.

Sotnikova, N. Y., Milkova, E. V., Kuznecov, O. Y., \& Martynova, A. A. (2001). Immunomoduliruyushchee dejstvie soka griba Shiitake in vitro [Immunomodulating effect of Shiitake mushrooms sap]. Uspekhi Medicinskoj Mikologii, 1, 286-288 (in Russian).

Sreenivasan, S., Sugumaran, A., Lachnimanan, Y., Latha, R., Vijenthi, D., \& Saravananm, S. (2010). In vitro antioxidant activity and hepatoprotective effects of Letinula edodes against paracetamol-induced hepatotoxicity. Molecules, $15,4478-4489$.

Taufiqur, R. (2012). Suiitake mushrooms: A tool of medicine. Bangladesh Journal of Medical Biochemistry, 5(1), 24-32.

Welbaum, G. E. (2015). Vegetable production and practices. CAB International.

Xu, X., Yan, H., Tang, J., Chen, J., \& Zhang, X. (2014). Polysaccharides in Lentinus edodes: Isolation, structure, immonomodulating activity and future prospective. Critical Reviews in Food Science and Nutrition, 54(4), 474-487.

Zhang, J. J., Li, Y., Zhou, T., Xu, D. P., Zhang, P., Li, S., \& Li, H. B. (2016). Bioactivities and health benefits of mushrooms mainly from China. Molecules, 21(7), e938. 